\title{
Conversion Efficiency of Photosynthetically Active Radiation for Soybean Cultivations in Spatial Arrangements
}

\author{
Braulio Otomar Caron ${ }^{1}$, Ana Paula Rockenbach ${ }^{2}$, Denise Schmidt ${ }^{1}$, Thaise Dieminger Engroff ${ }^{3}$, \\ Felipe Schwerz ${ }^{3} \&$ Julia Renata Schneider ${ }^{4}$ \\ 1 Departament of Agronomic and Environmental Sciences, Federal University of Santa Maria, Frederico \\ Westphalen Campus, Frederico Westphalen, Rio Grande do Sul, Brazil \\ ${ }^{2}$ Departament of Weed, Passo Fundo University, Passo Fundo, Rio Grande do Sul, Brazil \\ ${ }^{3}$ Department of Plant Science, Luiz de Queiroz College of Agriculture, University of São Paulo, Piracicaba, São \\ Paulo, Brazil \\ ${ }^{4}$ Departament of Plant Science, Passo Fundo University, Passo Fundo, Rio Grande do Sul, Brazil \\ Correspondence: Ana Paula Rockenbach, Departament of Weed, Passo Fundo University, BR 285, Bairro São \\ José, CEP: 99052-900, Passo Fundo, Rio Grande do Sul, Brazil. E-mail: anapagronomia@yahoo.com.br
}

Received: March 27, 2019

Accepted: April 30, 2019 Online Published: June 30, 2019

doi:10.5539/jas.v11n9p213

URL: https://doi.org/10.5539/jas.v11n9p213

The research is financed by National Council for Scientific and Technological Development (CNPq).

\begin{abstract}
The objective of this paper was to assess the efficiency of photosynthetically active radiation (PAR) intercepted in dried phytomass of soybean cultivars of determinate and indeterminate growth habits in different spatial arrangements. All experiments were carried out during the 2013/2014 crop year, two soybean cultivars (BMX Ativa RR/determinate and BMX Turbo RR/indeterminate) in a spatial arrangements (45, crossed, 20, $20 \times 40,20$ $\times 60,20 \times 80 \mathrm{~cm}$ ). Starting from first emergence up to the point of maturation, 14 phytomass assessment were evaluated with seven days interval, in which one plant was sampled per repetition. Greater conversion efficiencies of solar radiation were obtained in paired arrangements. Paired arrangements, and $20 \mathrm{~cm}$, lead to a greater leaf area index, and possibly a greater interception of the diffused radiation and an increase of conversion efficiency and the overall cultivation productivity of BMX Ativa RR and BMX Turbo RR.
\end{abstract}

Keywords: Glycine $\max$ L. Merril, growth habit, productivity, spacing

\section{Introduction}

Soybeans (Glycine $\max$ (L.) Merril) are a cultivation of major importance to both Brazilian agriculture, and the Brazilian economy. Spacing alternatives for cultivation have been studied, and compared with traditional systems composed of $45 \mathrm{~cm}$ between lines, as well as various spacing alternatives such as spacing reduction, crossed sowing, and paired line usage contained differentiated spacing on the internal and external interlines.

One of the main meteorological elements which influences crop growth is solar radiation; this factor has been the focus of recent research which highlights the relationship between this factor and yield and plant height (Kunz et al., 2007). However, due to the sensitivity of chloroplasts not all solar radiation which hits plants can be used in the conversion process (Assis \& Mendez, 1989). The only wavelengths of light used by plants, photosynthetically active radiation (PAR), represent photo flow from 400-700 nm; this range makes up 45-50\% of the total solar radiation (Assis \& Mendez, 1989).

After being provided with adequate amounts of water and nutrients, dried phytomass production was then mainly effected by the photosynthetically active radiation (PAR) interception. Thereby, intercepted PAR, when converted in phytomass can reveal the efficiency of radiation utilization by a species (Monteith, 1977), this can be determined by the angular coefficient of the linear regression between produced phytomass and intercepted photosynthetically active radiation (Kunz et al., 2007; Caron et al., 2012, 2014). 
The availability and utilization of solar radiation by plants is affected by many factors including: general structure, leaf angle and arrangement, population density, spacing, and by its physiology (Fagan et al., 2013). Soybean cultivations showed an elevated leaf area (LA) and a fast emergence of leaflets which leads to an increase in the interception of solar radiation until a certain point in which self-shading is and results in a greater light extinction coefficient. At this moment, even an increase in the leaf area index (LAI) would not increase interception (Casaroli et al., 2007), this factor is crucial to increasing the conversion efficiency of plants.

The objective of this paper was to assess plants conversion efficiency of photosynthetically active radiation by analyzing dried phytomass, and to examine soybean cultivations with cultivars of determinate and indeterminate growth in different spatial arrangements.

\section{Material and Methods}

\subsection{Plant Materials and Growth Conditions}

A field study was conducted in the city of Frederico Westphalen, Rio Grande do Sul, Brazil. In accordance with Köppen's climatic classification, the region's climate is considered Cfa. The experiment design was a randomized block, in a factorial design $(6 \times 2)$ having six spatial arrangements $(45$, crossed "cross-sowing in two directions", 20, and paired lines of $20 \times 40,20 \times 60$, and $20 \times 80 \mathrm{~cm}$ ) and two growth habits (determinate and indeterminate) of BMX Ativa RR/determinate and BMX Turbo RR/indeterminate, with three repetitions, achieving the amount of 36 sample parts. Sowing was carried out on December and fertilizer was applied manually at the time of sowing. Emergence was considered to occur when $50 \%$ of seedlings were above took place seven days after emergence, with planting density of 250.000 plants per hectare in all of the treatments.

\subsection{Evaluations}

Starting from the point of emergence and ending at physiological maturation, 14 weekly assessments were carried out. Including plant sampling repetition, a total of 504 plants were assessed during the cycle. Starting from cotyledons, leaves, stem, branches, flowers, pods, leftovers (senescent leaves and smaller than five centimeters), leaf discs were taken. These samples were later dried via a forced-air heated greenhouse $65^{\circ} \mathrm{C}$ air was forced through greenhouse, until a constant mass was reached.

The leaf area (LA) was calculated in $\mathrm{m}^{2}$ by the following equation:

$$
\mathrm{LA}=\left[\mathrm{n}^{\circ} \text { discs } \times \text { borer area } \times(\mathrm{DM} \text { leaves }+ \text { discs })\right] / \mathrm{DM} \text { leaf discs }
$$

Where, $\mathrm{n}^{\circ}$ discs is the number of discs made per sample, borer area refers to the area of the cork borer in $\mathrm{m}^{2}, \mathrm{DM}$ leaves + discs are the total dried material of the leaves in grams, and DM leaf discs is the discs dried material in grams.

The leaf area index (LAI) was determined from each plant's LA and the superficial area for each plant, with the following equation:

$$
\mathrm{LAI}=\mathrm{LA} / \mathrm{SS}
$$

Where, LA is the leaf area in $\mathrm{m}^{2}$, and SS is the soil area occupied by one plant in $\mathrm{m}^{2}$, which is $0.04 \mathrm{~m}^{2}$.

Global solar radiation was collected in an automatic station belonging to INMET (Instituto Nacional de Meteorologia). The incident active photosynthetic radiation was estimated to be $45 \%$ of the global solar radiation (Assis \& Mendez, 1989), having no distinction between cloudy and sunny days. The amount of intercepted photosynthetically active radiation (iPAR) was determined based on model Varlet-Grancher et al. (1989):

$$
\operatorname{iPAR}=0.95 \cdot(\text { inPAR }) \cdot\left(1-\mathrm{e}^{\mathrm{k} * \mathrm{LAI}}\right)
$$

Where, iPAR is the intercepted photosynthetically active radiation $\left(\mathrm{MJ} \mathrm{m}^{-2}\right)$, inPAR incident photosynthetically active radiation $\left(\mathrm{MJ} \mathrm{m}^{-2}\right)$, LAI is the leaf area index, and $\mathrm{k}$ is the coefficient of light extinction which in this case was 0.5. According to Pengelly et al. (1999), the light extinction coefficient may vary in-between 0.5 to 0.6 to soybean, considering a cycle average.

According to Monteith (1977), conversion efficiency can be calculated by analyzing the relationship between average dried phytomass production, and intercepted photosynthetically active radiation. The following equation:

$$
\mathrm{DPP}=\epsilon \mathrm{b} \cdot \mathrm{iPAR}
$$

Where, DPP is the dried phytomass production in $\mathrm{g} \mathrm{m}^{-2}, \epsilon \mathrm{b}$ is the conversion efficiency of iPAR in produced dried phytomass, in $\mathrm{g} \mathrm{MJ}^{-1}$, and $\mathrm{PAR}$ is the intercepted photosynthetically active solar radiation, in $\mathrm{MJ} \mathrm{\textrm {m } ^ { - 2 }}$. 


\subsection{Statistical Analysis}

The index data of the leaf area, beginning from the V7 stage of development until R5, was subjected to statistics analysis Statistical Analysis System Learning Edition 8.0 (SAS, 2003), and averages were compared by the Turkey test with $\mathrm{p}>0.05$. The grain harvests took place when cultivars reached a physiological point of maturation; collections took each took place in $1 \mathrm{~m}^{2}$ units. Plants were taken to and threshed and weighed in a lab, and posterior humidity was correction by $13 \%$. In order to compare the spatial arrangements, a recommended arrangement of $45 \mathrm{~cm}$ was used; this comparison was carried out via Statistical Analysis System Learning Edition 8.0 (SAS, 2003) Dunnett's test with $\mathrm{p}>0.05$.

\section{Results and Discussion}

Accumulated dried material showed a positive linear relation with intercepted photosynthetically active radiation. This was confirmed by a high coefficient of determination, and supported by an observed increase in dried material due to accumulated and intercepted active photosynthetic radiation; these findings were supported by Caron et al. (2012). Accumulated intercepted photosynthetically active radiation (iPAR) of soybean cultivation, throughout 100 days of assessment, the cultivars BMX Ativa RR and BMX Turbo RR varied from 470 to 612 $\mathrm{MJ} \mathrm{\textrm {m } ^ { - 2 }}$ and from 531 to $646 \mathrm{MJ} \mathrm{m}^{-2}$, respectively. The highest radiation figures were observed in the spatial arrangement of paired lines of $20 \times 40,20 \times 60$, and $20 \times 80 \mathrm{~cm}$, where a greater accumulation of dried material took place.

The cultivar BMX Ativa RR, with determinate growth habits, presented differences in conversion efficiency according to the spatial arrangements (Figure 1). In the arrangement of $45 \mathrm{~cm}$, the conversion efficiency of the total cycle was $0.97 \mathrm{~g} \mathrm{MJ}^{-1}$, this was considered low when compared to other samples, which presented $1.7 \mathrm{~g}$ $\mathrm{MJ}^{-1}, 1.34 \mathrm{~g} \mathrm{MJ}^{-1}, 1.31 \mathrm{~g} \mathrm{MJ}^{-1}, 1.32 \mathrm{~g} \mathrm{MJ}^{-1}$, and $1.78 \mathrm{~g} \mathrm{MJ}^{-1}$ for the arrangements of crossed seeding $20,20 \times 40$, $20 \times 60$, and $20 \times 80 \mathrm{~cm}$. This finding demonstrated that arrangement modification was in general positive. Arrangements of $20 \mathrm{~cm}$ paired lines presented the greatest conversion efficiencies when compared to other arrangements. The vegetative and reproductive phenological phases can be observed in Figure 1.
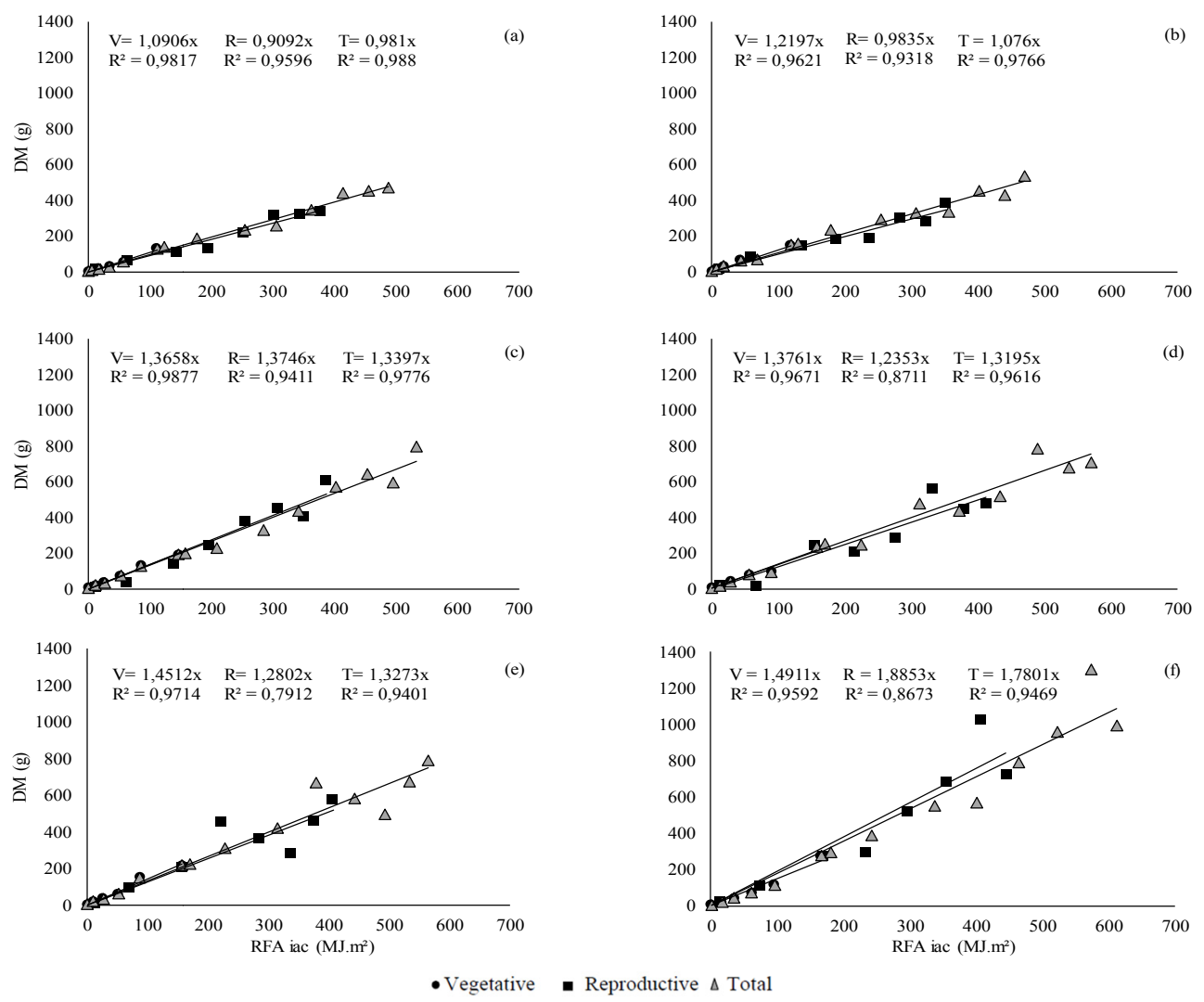

Figure 1. The Conversion efficiency $\left(\mathrm{g} \mathrm{MJ}^{-1}\right)$ of the vegetative $(\mathrm{V})$, and reproductive $(\mathrm{R})$ phases, and the total $(\mathrm{T})$ of the entire cycle of cultivar BMX Ativa RR with the spatial arrangements of $45 \mathrm{~cm}$ (a), crossed (b), $20 \mathrm{~cm}$ (c), 20 $\times 40 \mathrm{~cm}(\mathrm{~d}), 20 \times 60 \mathrm{~cm}(\mathrm{e}), 20 \times 80 \mathrm{~cm}(\mathrm{f})$ respectively 
In the cultivation of BMX Turbo RR, with indeterminate growth habit, similar findings were observed, and compared to the previous cultivation (Figure 2). With an arrangement of $45 \mathrm{~cm}$, BMX Turbo RR cultivation presented a smaller conversion efficiency in relation to the others with $1.00 \mathrm{~g} \mathrm{MJ}^{-1}$. The other arrangements, showed $1.21 \mathrm{~g} \mathrm{MJ}^{-1}$ on the crossed seeding, $1.38 \mathrm{~g} \mathrm{MJ}^{-1}$ in $20 \mathrm{~cm}, 1.59 \mathrm{~g} \mathrm{MJ}^{-1}$ in $20 \times 40 \mathrm{~cm}, 1.56 \mathrm{~g} \mathrm{MJ}^{-1}$ in $20 \times$ $60 \mathrm{~cm}$, and $1.50 \mathrm{~g} \mathrm{MJ}^{-1}$ in $20 \times 80 \mathrm{~cm}$. The greatest conversion efficiencies could be seen in the $20 \mathrm{~cm}$ of paired line arrangements in the reproductive and vegetative phases.
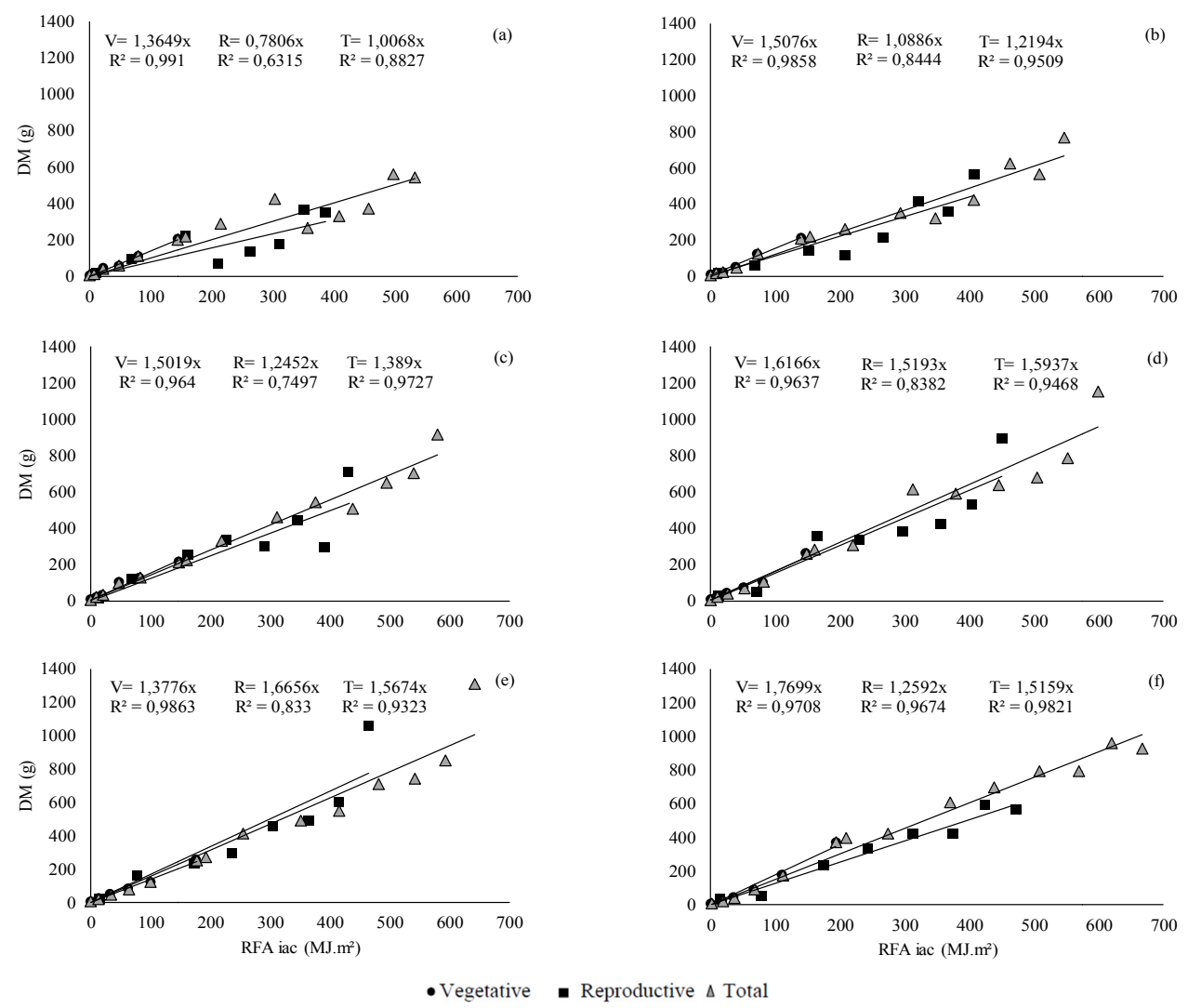

Figure 2. The Conversion efficiency $\left(\mathrm{g} \mathrm{MJ}^{-1}\right)$ of the vegetative $(\mathrm{V})$, and reproductive $(\mathrm{R})$ phases, and the total $(\mathrm{T})$ of the entire cycle of cultivar BMX Turbo RR with the spatial arrangements of $45 \mathrm{~cm}$ (a), crossed (b), $20 \mathrm{~cm}$ (c), 20 $\times 40 \mathrm{~cm}(\mathrm{~d}), 20 \times 60 \mathrm{~cm}(\mathrm{e}), 20 \times 80 \mathrm{~cm}(\mathrm{f})$ respectively

Arrangements of $45 \mathrm{~cm}$ during the reproductive phase of BMX Turbo RR cultivars, was the only sample which presented a great difference in the dried material reproduction between the R3 and R4, development stage of pods in February coincided with a low volume of precipitated of only $16.2 \mathrm{~mm}$ and the highest seasonal temperature, $36.7^{\circ} \mathrm{C}$. Water demand along the soybean cycle increases with plant development, and the periods of greatest demand are those between germination and emergence, and the period of flowering, in which, excesses and deficits can be harmful to establishing a uniform crop, and the growth leaves, flowers, and can lead to the death of soybean pods, which all results in a reduction of grain production (Manosso, 2005).

Given those findings one can infer that for this cultivation a modification of arrangement provided a better plant disposition and, consequently, better soil shading which might have favored its development and smaller sensitivity to the low precipitation volume. In annual cultivations, as with soybeans, management practices such as the sowing date, cultivation choice, spacing, and seeding density are factors which influence the development and consequently production of grain (Mauad et al., 2010). One way in which the interception of solar radiation may be increased is through the appropriate choice of plant arrangement to be used (Argenta et al., 2001).

The cultivars used in this study present distinct traits since the cultivar BMX Ativa RR has a determinate growth habit, and is relatively small-sized with few branches. BMX Turbo RR has indeterminate growth habit, is medium-sized with a high branching potential, these factors appeared to determine the different behavior to the spatial arrangements. The spacing reduction of $20 \mathrm{~cm}$, and paired lines increased the conversion efficiency of the 
cultivars; this is evidenced by a greater solar radiation interception, the greater radiation usage by leafs of the middle and inferior parts of the plants in paired lines, and a greater usage of diffused radiation due to an increase of the LAI.

Solar radiation interception is one of the determining factors of growth and development of any plant and, due to presented data on the efficiency of plants in different arrangements, it can be seen that plant arrangement is an important practice regarding cultivation management (Caron et al., 2012). The amount of energy converted in dried material depends on the absorption percentage and the usage efficiency of the intercepted energy (Argenta et al., 2001).

The best spatial arrangement is the one which provides the most uniform distribution of plants per area, enabling greater utilization of light, nutrients, and water use (Argenta et al., 2001). When a system of paired-lined sowing is used, the external interlines of the systems can compensate for the internal interline where greater competition for space exists. It provides, then, a better a leaf distribution along plant's main stem; aside from taking more time closing by reducing the potential for soybean cultivations to develop closed canopies, it favors leaves of the inferior (third) section, and helps the application of phytosanitary products (e.g., pesticides, herbicides) (Holtz et al., 2014).

Solar radiation interception is dependent on the leaf area index (LAI) and on the light extinction coefficient (k). Soybeans present an elevated leaf area and a rapid rate of leaflet growth which leads to increased radiation interception, this all results in substantial ground shadowing and plant competition (Casaroli et al., 2007). This increase in LAI occurs after the self-shading results in a greater light extinction coefficient as well, even if LAI is increased, there is an increase of intercepted radiation.

The critical value of LAI necessary to intercept 95\% of solar radiation is 3.9 (Schöffel \& Volpe, 2001). This value is influenced by a cultivar's phenological state and spatial arrangement, as was observed by Heiffig et al. (2006) while working with soybeans of different spacing and plant densities. The maximum LAI in the R5 phenological state which corresponds to the beginning of grain filling was found in the spacing design 0.20 to $0.60 \mathrm{~m}$ between the lines (interlines).

In this case, the maximum LAI reached by the cultivar BMX Ativa RR was 5.0 in R5, and in BMX Turbo RR it was 5.4 in R3. Both cultivars were grown in a paired arrangement of $20 \times 80 \mathrm{~cm}$ (Table 1). These phenological phases are extremely important to soybean development when intensification begins; during grain filling, the plant's water, nutrients, and photoassimilates demands are greater (Heiffig et al., 2006). Generally, a linear increase was observed in LAI during the stadiums and the superiority of the reproductive stadiums.

For the cultivar BMX Turbo RR, the maximum LAI was on phenological phases R1 and R3, when greater LAI of the cultivation was observed, with 5.8 (LAI) on the $20 \times 80 \mathrm{~cm}$ arrangement, being equal to $20 \times 60 \mathrm{~cm}$ with 4.8 (LAI); this is different from the other arrangements. Similar to the previous cultivar, BMX Ativa RR, also presented a linear increase in LAI as it moved from one phenological stage to the next. The spatial arrangement with paired lines added on both cultivations LAI. Equally, it was verified positive response with conversion efficiency previously presented, since these arrangements were superior to others.

The increase of conversion efficiency is likely related to the greater LAI and associated with an increased usage of diffused radiation that was available in these arrangements. Since it is multi-directional, diffused radiation is more efficient at penetrating the vegetal canopy when compared to direct radiation, which is unidirectional and causes self-shading of the inferior leaves (Buriol et al., 1995). 
Table 1. Leaf area index of the soybean cultivars BMX Ativa RR and BMX Turbo RR in different phenological phases, and in spatial arrangements

\begin{tabular}{|c|c|c|c|c|c|c|c|c|c|c|c|c|c|c|}
\hline \multirow{4}{*}{$\begin{array}{l}\text { Spatial arrangements } \\
(\mathrm{cm}) \\
45\end{array}$} & \multicolumn{14}{|c|}{ Phenological phases } \\
\hline & \multicolumn{14}{|c|}{ BMX Ativa RR } \\
\hline & \multicolumn{2}{|l|}{ V7 } & \multicolumn{2}{|l|}{ V8 } & \multicolumn{2}{|l|}{ R1 } & \multicolumn{2}{|l|}{$\mathrm{R} 2$} & \multicolumn{2}{|l|}{ R3 } & \multicolumn{2}{|l|}{ R4 } & \multicolumn{2}{|c|}{ R5 } \\
\hline & 0.7 & $\mathrm{aB}^{*}$ & 1.1 & $\mathrm{abB}$ & 2.4 & $\mathrm{bA}$ & 3.0 & $\mathrm{bA}$ & 2.6 & $\mathrm{bA}$ & 2.4 & $\mathrm{bA}$ & 2.9 & $\mathrm{bcA}$ \\
\hline crossed & 1.1 & $\mathrm{aB}$ & 1.0 & $\mathrm{bB}$ & 2.2 & $\mathrm{bAB}$ & 2.5 & $\mathrm{bA}$ & 2.5 & $\mathrm{bA}$ & 2.5 & $\mathrm{bA}$ & 2.0 & $\mathrm{cAB}$ \\
\hline 20 & 1.3 & $\mathrm{aB}$ & 1.7 & $\mathrm{aB}$ & 2.5 & $\mathrm{bAB}$ & 2.5 & $\mathrm{bAB}$ & 2.7 & $\mathrm{bA}$ & 3.2 & $\mathrm{abA}$ & 3.0 & $\mathrm{bcA}$ \\
\hline $20 \times 40$ & 1.4 & $\mathrm{aC}$ & 1.7 & $\mathrm{aBC}$ & 3.4 & $\mathrm{abAB}$ & 2.7 & $\mathrm{bB}$ & 4.1 & $\mathrm{aA}$ & 3.1 & $\mathrm{bAB}$ & 3.3 & $\mathrm{bAB}$ \\
\hline $20 \times 60$ & 1.1 & $\mathrm{aC}$ & 2.3 & $\mathrm{aB}$ & 3.2 & $\mathrm{abAB}$ & 3.4 & $\mathrm{abAB}$ & 3.7 & $\mathrm{abAB}$ & 4.3 & $\mathrm{aA}$ & 3.3 & $\mathrm{bAB}$ \\
\hline \multirow[t]{3}{*}{$20 \times 80$} & 1.1 & $\mathrm{aC}$ & 2.0 & $\mathrm{aC}$ & 3.8 & $\mathrm{aA}$ & 4.3 & $\mathrm{aA}$ & 4.8 & $\mathrm{aA}$ & 3.7 & $\mathrm{abB}$ & 5.0 & $\mathrm{aA}$ \\
\hline & \multicolumn{14}{|c|}{ BMX Turbo RR } \\
\hline & \multicolumn{2}{|l|}{ V7 } & \multicolumn{2}{|l|}{ V8 } & \multicolumn{2}{|l|}{$\mathrm{R} 1$} & \multicolumn{2}{|c|}{$\mathrm{R} 2$} & \multicolumn{2}{|l|}{ R3 } & \multicolumn{2}{|l|}{ R4 } & \multicolumn{2}{|c|}{ R5 } \\
\hline 45 & 1.0 & $\mathrm{aB}$ & 1.7 & $\mathrm{aB}$ & 3.0 & $\mathrm{bAB}$ & 3.5 & $\mathrm{aA}$ & 3.7 & $\mathrm{bA}$ & 2.2 & $\mathrm{bAB}$ & 2.3 & $\mathrm{aAB}$ \\
\hline crossed & 0.9 & $\mathrm{aB}$ & 2.0 & $\mathrm{aAB}$ & 3.1 & $\mathrm{bA}$ & 3.1 & $\mathrm{aA}$ & 3.3 & $\mathrm{bA}$ & 2.7 & $\mathrm{bA}$ & 3.2 & $\mathrm{aA}$ \\
\hline 20 & 1.6 & $\mathrm{aB}$ & 1.8 & $\mathrm{aB}$ & 3.1 & $\mathrm{bAB}$ & 3.9 & $\mathrm{aA}$ & 4.3 & $\mathrm{abA}$ & 4.1 & $\mathrm{abA}$ & 3.3 & $\mathrm{aAB}$ \\
\hline $20 \times 40$ & 1.1 & $\mathrm{aB}$ & 1.5 & $\mathrm{aB}$ & 3.6 & $\mathrm{bA}$ & 3.5 & $\mathrm{aA}$ & 5.0 & $\mathrm{abA}$ & 4.2 & $\mathrm{abA}$ & 4.3 & $\mathrm{aA}$ \\
\hline $20 \times 60$ & 1.3 & $\mathrm{aB}$ & 2.2 & $\mathrm{aB}$ & 4.8 & $\mathrm{abA}$ & 4.7 & $\mathrm{aA}$ & 4.5 & $\mathrm{abA}$ & 4.0 & $\mathrm{abA}$ & 4.4 & $\mathrm{aA}$ \\
\hline $20 \times 80$ & 1.8 & $\mathrm{aC}$ & 3.0 & $\mathrm{aBC}$ & 5.8 & $\mathrm{aA}$ & 4.1 & $\mathrm{aB}$ & 5.4 & $\mathrm{aA}$ & 5.4 & $\mathrm{aA}$ & 4.7 & $\mathrm{aA}$ \\
\hline
\end{tabular}

Note. *Averages followed by the same lowercase letters on the column and capital letters on the line are not differentiated among themselves by Turkey's test $\mathrm{p}>0.05$.

Elli et al. (2013), when assessing solar radiation interception of soybeans under distinct spatial arrangements, observed that the arrangements $20 \times 40,20 \times 60$, and $20 \times 80 \mathrm{~cm}$ intercepted $92 \%$ of radiation in the R5 phenological phase, where grain filling is initiated; this is extremely important so that the plant may intercept maximum levels of radiation and convert solar energy to phytomass. These authors affirm that the spatial arrangement and phenological phase influence soybean cultivations' interception of radiation since there is a variation in responses, due to these two factors.

Grain production in the cultivars followed the same tendency, of which arrangements of $20 \mathrm{~cm}$, and paired lines were the most productive when compared with recommended arrangement of $45 \mathrm{~cm}$ (Table 2). Only the cultivar BMX Turbo RR in the arrangements of 20 and $20 \times 40$ displayed a statistically significant, superior difference in productivity, supporting previous findings, since the conversion efficiency and the LAI was also greater in these arrangements.

Table 2. Productivity $\left(\mathrm{kg} \mathrm{ha}^{-1}\right)$ of the soybean cultivars BMX Ativa RR and BMX Turbo RR in different spatial arrangements compared to the recommended arrangement of $45 \mathrm{~cm}$

\begin{tabular}{lll}
\hline Spatial arrangements $(\mathrm{cm})$ & BMX Ativa RR & BMX Turbo RR \\
\hline 45 & 2744.6 & 2114.0 \\
crossed & 2196.3 & 3091.3 \\
20 & 2748.0 & $3771.3+$ \\
$20 \times 40$ & 3266.0 & $3884.0+$ \\
$20 \times 60$ & 2671.7 & 2871.6 \\
$20 \times 80$ & 2522.3 & 3046.0 \\
\hline
\end{tabular}

Note. ${ }^{+}$Statistically significant, greater differences to the recommended arrangement of $45 \mathrm{~cm}$ by the Dunnett's test $\mathrm{p}>0.05$.

Spatial arrangements led to greater productivity as was observed by Mattioni et al. (2008). Whereas paired lines enabled the plant to compensate for the smaller spacing of the internal interlines due to the presence of external interline, thereby favoring growth and development and leading to an increase in productivity (Carvalho et al., 2013). Therefore, more studies need to be carried out considering spatial arrangements with regards to cultivations and agriculture years, in order to discover the best assessment and possible recommendation. 


\section{Conclusions}

The greatest conversion efficiencies of the cultivars were obtained in paired arrangements. In the paired arrangements, and $20 \mathrm{~cm}$ spatial arrangement, due to a greater leaf area index and possibly greater interception of diffused radiation, an increase in conversion efficiency and productivity was observed for the cultivars BMX Ativa RR and BMX Turbo RR.

\section{References}

Argenta, G., Silva, Pr. Da, \& Sangoi, L. (2001). Maize plant arrangement: Analysis of the state of the art. Ciência Rural, 31(6), 1075-1084. https://doi.org/10.1590/S0103-84782001000600027

Assis, F. N. De, \& Mendez, M. E. G. (1989). Relationship between photosynthetically active radiation and global radiation. Pesquisa Agropecuária Brasileira, 24(7), 797-800.

Buriol, G. A., Streck, N. A., Petry, C., \& Schneider, F. M. (1995). Solar radiation transmissivity through low density polyenthylene used in greenhouses. Ciência Rural, 25(1), 1-4. https://doi.org/10.1590/S010384781995000100001

Carvalho, L. C., Bueno, C. O. F., Carvalho, M. M., Favoreto, A. L., \& Godoy, A. F. (2013). New techniques of arrangements for seeding in soybean crop. Enciclopédia Biosfera, 9(17), 1940-1954.

Caron, B. O., Souza, V. Q. De, Trevisan, R., Behling, A., Schmidt, D., Bamberg, R., \& Eloy, E. (2012). Efficiency of the conversion of photosynthelically active radiation dry biomass in eucalyptus seedlings. Revista Árvore, 36(5), 833-842. https://doi.org/10.1590/S0100-67622012000500005

Caron, B. O., Schmidt, D., Manfron, P. A., Behling, A., Eloy, E., \& Busanello C. (2014). Efficiency of the use of solar radiation for plants Ilex paraguariensis A. St. Hil. cultivated under shadow and full sun. Ciência Florestal, 24(2), 257-265. https://doi.org/10.5902/1980509814563

Casaroli, D., Fagan, E. B., Simon, J., Medeiros, S. P., Manfron, P. A., Neto, D., ... Martin, T. N. (2007). Solar radiation and physiologics aspects in soybean-A review. Revista da FZVA, 14(2), 102-120.

Elli, E. F., Caron, B. O., Rockenbach, A. P., Schmidt, D., \& Eloy, E. (2013). Influence of different phenological stages and spatial arrangements in the interception of global radiation on soybean cultivars. Enciclopédia Biosfera, 9(16), 1288-1297.

Fagan, E. B., Miquelanti, N. P., Bonfim, T. S., Pereira, I. S., Corrêa, L. T., \& Soares, J. N. (2013). Beer Law and its relations with plants. Cerrado Agrociências, 4, 78-97.

Heiffig, L. S., Câmara, M. S., Marques, L. A., Pedroso, D. B., \& Piedade, S. M. S. (2006). Closed canopy and leaf area index of soybean in different space arrangements. Bragantia, 65(2), 285-295. https://doi.org/ $10.1590 / \mathrm{S} 0006-87052006000200010$

Holtz, V., Couto, R. F., Oliveira, D. G. \& Reis, E. F. (2014). Deposition of spray solution and productivity of soybean cultivated in different spatial arrangements. Ciência Rural, 44(8), 1371-1376. https://doi.org/ $10.1590 / 0103-8478 \mathrm{cr} 20130783$

Kunz, J. H., Bergonci, J. I., Bergamaschi, H., Dalmago, G. A., Heckler, B. M. M., \& Comiran, F. (2007). Interception and use of solar radiation by maize, as modifying soil tillage, row spacing and irrigation water availability. Pesquisa Agropecuária Brasileira, 42(11), 1511-1520. https://doi.org/10.1590/S0100-204X 2007001100001

Manosso, P. C. (2005). The productivity of soy, wheat and maize and its relations with precipitation in the city of Apucarana-PR in the period between 1968 and 2002. Revista do Departamento de Geociencias, 14(1), 87-98.

Mauad, M., Silva, T. L. B., Neto, A. I. A., \& Abreu, V. G. (2010). The influence of sowing density on agronomic characteristics of soybean crop. Revista Agrarian, 3(9), 175-181.

Mattioni, F., Côrrea, L. A. V., Gomes, J. C. C., \& Wünch, J. (2008). Space arrangements, weeds and soybean (Glycine max (Linn) Merril) agronomic characteristics in organic farming. Revista Brasileira Agrociência, 14(3), 21-32.

Monteith, J. L. (1977). Climate and the efficiency of crop production em Britain. Proceedings of the Royal Society of London, 281, 277-294. https://doi.org/10.1098/rstb.1977.0140 
Pengelly, B. C., Blamey, F. P. C., \& Muchow, R. C. (1999). Radiation interception and the accumulation of biomass and nitrogen by soybean and three tropical annual forage legumes. Field Crops Research, 63(2), 99-112. https://doi.org/10.1016/S0378-4290(99)00029-5

Sas Learning Edition. (2003). Getting started with the SAS Learning Edition (p. 200). Cary.

Schöffel, E. R., \& Volpe, C. A. (2001). Efficiency in conversion of photosynthetically active radiation intercepted by soybean to biomass production. Revista Brasileira de Agrometeorologia, 9(2), 241-249.

Varlet-Grancher, C., Gosse, G., Chartier, M., Sinoquet, H., Bonhomme, R., \& Allirand, J. M. (1989). Mise au point: Rayonnement solaire absorbé ou intercepté par um couvert végétal. Agronomie, 9(5), 419-439. https://doi.org/10.1051/agro:19890501

\section{Copyrights}

Copyright for this article is retained by the author(s), with first publication rights granted to the journal.

This is an open-access article distributed under the terms and conditions of the Creative Commons Attribution license (http://creativecommons.org/licenses/by/4.0/). 